\title{
PENENTUAN PRIORITAS PENGELOLAAN DAERAH ALIRAN SUNGAI DELI MENGGUNAKAN INDEKS POTENSI EROSI
}

\author{
Khairi Fadhlan, A. Perwira Mulia Tarigan, dan Zaid Perdana Nasution \\ Universitas Sumatera Utara (USU) Medan, Indonesia \\ Email: khairifadhlan.kf@gmail.com, a.perwira@usu.ac.id,dan mas_zaid@yahoo.com
}

\begin{abstract}
Due to resource constraint, it is often impractical to implement the watershed management for mitigating soil erosion problem in the whole, large catchment area. Hence watershed prioritization is a sensible approach in which different micro watersheds of a watershed are ranked according to the order of priority to be treated with suitable soil conservation measures. The purpose of this study is to determine the priority or the rank of the micro watersheds of Deli River using the erosion potential index (EPI) method, indicative of erosional capacity. The EPI in this study is assessed using 5 layers of spatial information in a GIS format, i.e. land cover, soil condition, land slope, drainage density, and rainfall. All these layers are integrated and then combined linearly using weights determined with AHP method. The results show that the total area under high to very high priority are around 36 micro watersheds out of 53 watersheds, emphasizing the necessity for watershed management.
\end{abstract}

Keywords: AHP; Erosion; GIS; Priorities; Watershed

\begin{abstract}
Abstrak
Karena keterbatasan sumber daya, pengimplementasian pengelolaan DAS sering dinilai tidak praktis untuk mengatasi masalah erosi tanah pada daerah tangkapan air yang luas. Maka dari itu, penentuan prioritas DAS menjadi pendekatan yang masuk akal dengan membuat urutan mikro DAS sesuai prioritas perawatan yang menggunakan perhitungan konservasi tanah yang sesuai. Tujuan dari penelitian ini adalah menentukan prioritas mikro DAS pada sungai Deli menggunakan metode indeks potensial erosi (EPI) yang menunjukkan kapasitas erosi. EPI dalam penelitian ini diukur menggunakan lima aspek informasi spasial dalam format GIS, yakni tutupan lahan, kondisi tanah, kemiringan lahan, kerapatan sungai, dan curah hujan. Semua aspek tersebut terintegrasi dan dikombinasikan secara linier menggunakan bobot yang ditentukan dengan metode AHP. Hasil penelitian menunjukkan bahwa jumlah keseluruhan yang berada pada prioritas tinggi hingga sangat tinggi adalah sebanyak 36 mikro DAS dari 53 DAS. Hal ini menekankan kebutuhan pengelolaan DAS.
\end{abstract}

Kata Kunci: AHP; DAS; erosi; GIS; prioritas

\begin{tabular}{ll}
\hline How to cite: & Fadhlan, Khairi., A. Perwira Mulia Tarigan, dan Zaid Perdana Nasution (2021) Penentuan Prioritas \\
& Pengelolaan Derah Aliran Sungai Deli Menggunakan Indeks Potensi Erosi, Syntax Literate 6(5). \\
& http://dx.doi.org/10.36418/syntax-literate.v6i5.2702 \\
E-ISSN: & 2548-1398 \\
Published by: & Ridwan Institute
\end{tabular}




\section{Pendahuluan}

Penilaian resiko erosi tanah pada DAS (daerah aliran sungai) membutuhkan pemetaan dan banyak faktor yang di analisis (Vrieling, 2006). Erosi tanah yang disebabkan oleh air dianggap sebagai hilangnya permukaan tanah yang disebabkan oleh hujan dan limpasan. Erosi tanah yang disebabkan oleh air saat ini adalah masalah yang sangat penting di seluruh dunia, setelah masalah perubahan iklim (Fallah, Kavian, \& Omidvar, 2016); (Terranova, Antronico, Coscarelli, \& Iaquinta, 2009). Jumlah erosi diukur dengan jumlah kehilangan tanah dalam setahun. Data menunjukkan bahwa ratarata erosi pada DAS Deli yaitu sebesar 138,808 tn/ha/thn atau 6.565.344,948 tn/thn (Isma, Irwansyah, \& Neneng, 2017). Oleh karena itu perlu dilakukan pengelolaan, pemulihan, dan konservasi pada DAS Deli. Kegiatan pengelolaan DAS saat ini menjadi masalah karena terbatasnya biaya dan sumber daya sehingga perlu dilakukan prioritisasi DAS dalam ukuran mikro DAS. Pengalaman di lapangan ukuran mikro DAS adalah lebih kurang 1000 ha (Purwanto, Beny, H., dan Agung, 2016). Prioritisasi DAS adalah suatu proses perangkingan DAS sesuai dengan urutan yang paling penting untuk dilakukan penanganan baik pengelolaan maupun pemulihan kondisi DAS. (Nanda, A.M., Aadil, H.M., Zahoor, U.H., Pervez, A. dan Tasawoor, 2015); (Pandey, Chowdary, \& Mal, 2007).

Kegiatan pemulihan DAS yang paling utama adalah dengan melestarikan tanah dan air (Welde, 2016) sehingga pendekatan yang paling baik dalam memilih DAS prioritas untuk di pulihkan adalah dengan pendekatan penilaian kehilangan tanah (soil loss). Metode yang banyak digunakan untuk memprioritaskan daerah aliran sungai dengan penilaian kehilangan tanah adalah metode Universal Soil Loss Equation (USLE) (Wischmeier \& Smith, 1978); (Tetzlaff \& Wendland, 2012), metode USLE adalah suatu model erosi yang dirancang untuk memprediksi rata-rata erosi jangka panjang dari erosi lembar atau alur dibawah keadaan tertentu.

Pada penelitian ini Indeks Potensi Erosi berbasis AHP (Analytic Hierarchy Process) dan GIS (Geographical Information System) digunakan untuk memprioritisasikan daerah aliran sungai dalam ukuran mikro DAS. AHP adalah merupakan suatu model keputusan yang dapat membantu dalam menguraikan masalah dalam menentukan keputusan menjadi suatu hirarki (keputusan). Hirarki merupakan suatu representasi dari sebuah permasalahan yang kompleks dalam suatu struktur multi level, dimana level pertama adalah tujuan, diikuti level faktor, kriteria, sub kriteria, dan seterusnya hingga level terakhir alternatif (Saaty T L, 1980). GIS adalah sebuah sistem atau teknologi berbasis komputer yang dibuat untuk tujuan mengumpulkan, menyimpan, mengolah dan menganalisa, serta menyajikan data atau informasi dari suatu obyek atau fenomena yang berkaitan dengan letak atau keberadaannya di permukaan bumi (Ekadinata, Dewi, Hadi, Nugroho, \& Johana, 2008). AHP merupakan metode yang sangat baik digunakan dalam penelitian tentang pengambilan keputusan seperti penggunaan dalam pengelolaan sumber daya air yang dilakukan oleh (Tarigan, Rahmad, Sembiring, \& Iskandar, 2018) dan penentuan prioritas penanganan jalan (Tarigan, A. P. M., Surbakti, M. S., Sembiring, 2017), dan GIS membantu dalam 
pengolahan data-data spasial sehingga penelitian dapat dilakukan dengan lebih baik seperti yang diterapkan pada penelitian tentang mitigasi banjir (Tarigan et al., 2018) dan penelitian tentang prediksi banjir (Siregar, Tarigan, Irsan, \& Irwandi, 2019).

Indeks Potensi Erosi adalah nilai tanpa satuan yang membantu dalam pengindeksan zona potensi erosi pada daerah aliran sungai, nilai indeks yang lebih tinggi menunjukkan prioritas yang lebih tinggi. Indeks potensi erosi dihitung menggunakan parameter seperti data tutupan lahan, data tanah, kemiringan lahan, kerapatan sungai, dan data curah hujan yang diintegrasikan dalam penggunaan GIS dengan menetapkan bobot untuk masing-masing parameter menggunakan teknik AHP. Indeks potensi erosi pada penelitian ini berdasarkan dari metode Sediment Yield index (SYI) (Bali \& Karale, 1977); (Naqvi, Athick, Ganaie, \& Siddiqui, 2015). Metode indeks potensi erosi ini memiliki kelebihan karena mudah digunakan dan data yang diperlukan mudah didapatkan.

Uraian di atas menunjukkan pentingnya dilakukan penelitian tentang prioritas pengelolaan DAS karena luasnya daerah aliran sungai yang harus di lakukan pengelolaan dan konservasi. Perbedaan dengan penelitian yang telah dilakukan oleh peneliti terdahulu yang telah di sebutkan di atas adalah pada penelitian ini kriteria untuk menentukan prioritas pengelolaan daerah aliran sungai terdiri dari 5 (lima) kriteria yaitu tutupan lahan, jenis tanah, kemiringan lahan, kerapatan sungai dan curah hujan. Datadata yang digunakan sebagai kriteria merupakan data yang didapat dari lokasi penelitian. Tujuan dari penelitian ini adalah untuk mendapatkan urutan prioritas pengelolaan daerah aliran sungai Deli sebagai dasar untuk dilakukan pengelolaan dan konservasi daerah aliran sungai.

\section{Metode Penelitian}

Penentuan prioritas pengelolaan DAS Deli pada penelitian ini dalam ukuran mikro DAS. Langkah awal adalah membuat batas DAS Deli dalam ukuran mikro menggunakan data Digital Elevation Model (DEM) dengan bantuan perangkat lunak QGIS. Selanjutnya menghitung indeks potensi erosi (IPE) pada setiap mikro DAS dengan menetapkan bobot untuk setiap kriteria utama dengan metode AHP dan menentukan bobot untuk setiap subkriteria dengan perangkingan seperti dapat dilihat pada Gambar 1. Bobot kriteria dan bobot subkriteria dikalikan untuk mendapatkan nilai IPE. 


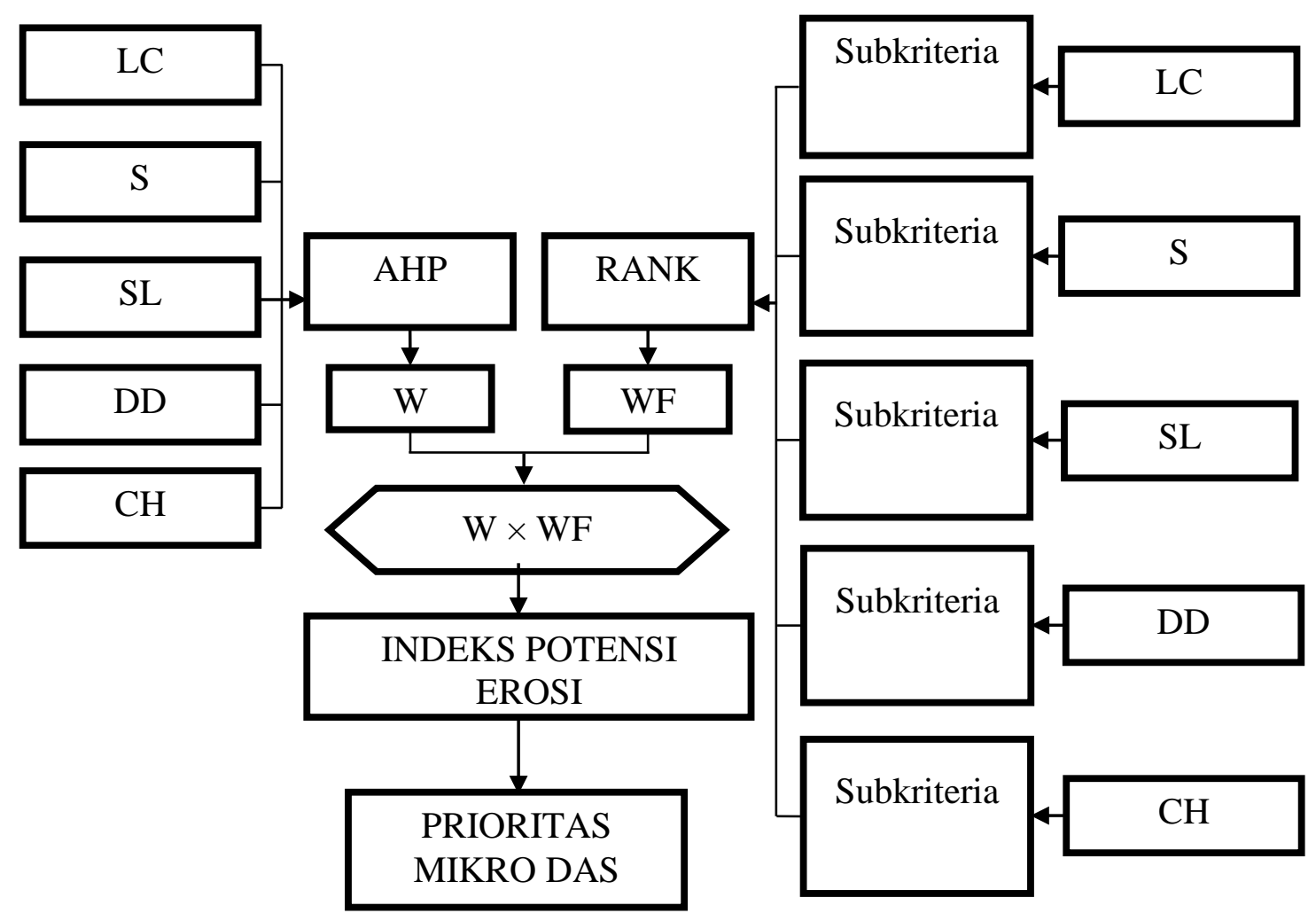

Gambar 1

\section{Langkah menghitung Indeks Potensi Erosi}

Bobot kriteria utama yang dihitung dengan metode AHP adalah dengan membuat peringkat pada skala AHP Saaty 1-9 untuk setiap kriteria yang telah ditentukan. Langkah dalam perhitungan dengan metode AHP adalah setiap kriteria tersebut diberi peringkat dengan dibandingkan satu sama lain dalam matriks perbandingan berpasangan. Penentuan peringkat dari matriks berpasangan dilakukan dengan metode penilaian para ahli atau dengan metode yang disepakati oleh para ahli serta berdasarkan jurnal-jurnal ilmiah yang terkait dengan penelitian ini. Hasil dari bobot yang didapat kemudian dihitung nilai sintesis matriks untuk mendapatkan konsistensi dari hasil yang didapat yaitu dengan persyaratan nilai $\mathrm{CR}<0,1$. Data-data yang digunakan pada penelitian ini yaitu peta tanah (S), peta tutupan lahan (LC) yang didapat dari Balai Pengelolaan Daerah Aliran Sungai dan Hutan Lindung Wampu Sei Ular, peta kemiringan lahan (SL) yang dibuat dengan perangkat lunak QGIS menggunakan data DEM NAS, peta kerapatan sungai (DD) dari hasil perhitungan, dan peta curah hujan (R) dari Badan Meteorologi Klimatologi Geofisika (BMKG). Bobot untuk setiap subkriteria ditentukan dengan perangkingan. Nilai rangking untuk setiap kelas subkriteria tersebut adalah berdasarkan review dari beberapa jurnal dan diskusi dengan para ahli.

Rumus matematis untuk menghitung Indeks Potensi Erosi (IPE) pada setiap mikro DAS adalah yang dimodifikasi dari (Chowdary et al., 2013) sebagai berikut: 


$$
I P E_{w}=\frac{\sum_{i=1}^{N}\left(A_{i} \times I P E_{i}\right)}{A_{W}}
$$

Di mana, $N$ adalah number of erosive unit ( $E U$ ) pada masing-masing mikro DAS (EU) adalah poligon yang terbentuk akibat dari peta masing-masing kriteria memotong kriteria yang lain), $A_{i}$ adalah luas dari setiap $E U$, IIPE adalah Indeks Potensi erosi, dan $A w$ adalah luas mikro DAS yang dihitung menggunakan rumus:

$$
A_{w}=\sum_{i=1}^{N} A_{i}
$$

Selanjutnya indeks potensi erosi (IPE) pada setiap erosive units yang terbentuk dihitung menggunakan rumus:

$$
I P E_{i}=S_{w} S_{w f}+S L_{w} S L_{w f}+L C_{w} L C_{w f}+D D_{w} D D_{w f}+R_{w} R_{w f}
$$

Di mana, S adalah tanah, SL adalah kemiringan lahan, LC adalah tutupan lahan, DD adalah kerapatan sungai, $\mathrm{R}$ adalah curah hujan, $\mathrm{W}$ adalah bobot dari kriteria utama yang dihitung menggunakan AHP, dan wf adalah bobot dari sub kriteria yang dihitung menggunakan metode perangkingan.

Bobot kriteria utama dikalikan dengan bobot subkriteria untuk mendapatkan nilai Indeks Potensi Erosi (IPE), kemudian nilainya diurutkan mulai dari yang paling besar sampai dengan sangat kecil. Nilai yang paling besar menjadi prioritas utama untuk dilakukan pengelolaan dan konservasi. Nilai IPE tersebut juga dikelompokkan menjadi 4 kelas prioritas yaitu sangat tinggi, tinggi, sedang, dan rendah. pengelompokkan kelas berdasarkan pada metode natural breaks pada perangkat lunak QGIS.

Lokasi penelitian adalah DAS Deli yang berada di kabupaten Deli Serdang, Kabupaten Karo, dan kota Medan, Provinsi Sumatera Utara, Indonesia. Adapun batas DAS Deli adalah Sebelah Utara: Daerah Aliran Sungai Belawan, Sebelah Selatan: Daerah Aliran Sungai Wampu, Sebelah Barat: Daerah Aliran Sungai Belawan, dan Sebelah Timur: Daerah Aliran Sungai Percut.

\section{Hasil dan Pembahasan}

Batas DAS Deli yang dibuat dalam ukuran mikro DAS menggunakan perangkat lunak QGIS menghasilkan 53 mikro DAS. Setiap mikro DAS diberi nama mulai dari MW1 sampai dengan MW53 berurutan dari hilir DAS Deli sampai daerah hulu DAS Deli. Luas mikro DAS yang paling besar adalah pada mikro DAS MW28 dengan luas 1.895 ha, sedangkan mikro DAS dengan luas paling kecil adalah mikro DAS MW1 dengan luas 314 ha. Peta batas DAS Deli dalam ukuran mikro dapat dilihat pada Gambar 2. 


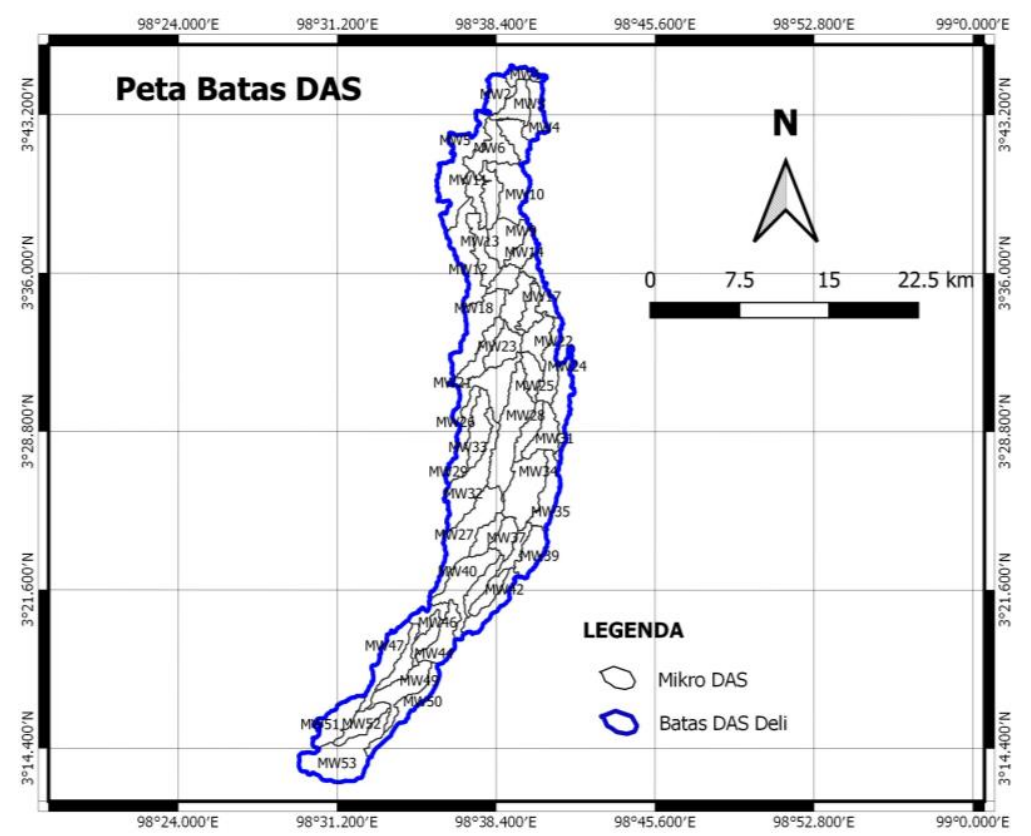

Gambar 2

Batas DAS Deli

Setiap mikro DAS yang terdiri dari 53 mikro DAS dihitung nilai indeks potensi erosi, nilai indeks potensi erosi yang paling besar menjadi prioritas utama dalam pengelolaan dan konservasi DAS secara terpadu. Prioritas ini juga diklasifikasi menjadi kategori sangat tinggi, tinggi,sedang, dan rendah. Selanjutnya untuk mendapatkan nilai indeks potensi erosi pada setiap mikro DAS adalah menghitung bobot kriteria dengan menggunakan metode AHP.

\section{Bobot Kriteria}

Matriks perbandingan dan nilai bobot untuk setiap kriteria yang dihitung menggunakan metode AHP dapat dilihat pada Tabel 1. Nilai perbandingan kriteria di modifikasi dari dan hasil diskusi dengan para ahli.

Tabel 1

Matriks perbandingan dan bobot kriteria

\begin{tabular}{lcccccc}
\hline KRITERIA & Tutupan Lahan & Tanah & Lereng & DD & C. Hujan & Bobot \\
\hline $\begin{array}{l}\text { Tutupan } \\
\text { Lahan }\end{array}$ & 1.00 & 6.00 & 4.00 & 3.00 & 5.00 & 0.46 \\
\hline Tanah & 0.17 & 1.00 & 0.33 & 0.20 & 2.00 & 0.07 \\
\hline Lereng & 0.25 & 3.00 & 1.00 & 0.33 & 3.00 & 0.14 \\
\hline DD & 0.33 & 5.00 & 3.00 & 1.00 & 4.00 & 0.26 \\
\hline C. Hujan & 0.20 & 0.50 & 0.33 & 0.25 & 1.00 & 0.06 \\
\hline
\end{tabular}

\section{Bobot Subkriteria}

Setiap kriteria memiliki subkriteria, subkriteria tutupan lahan adalah hutan mangrove sekunder (Hms), hutan lahan kering (Hs), hutan lahan kering primer (Hp), Perkebunan (Pk), Belukar Rawa (Br), Belukar (B), pertanian lahan kering (Pt), tanah 
terbuka (T), Tambak (Tm), sawah (Sw), pemukiman (Pm), bandara (lanud), badan air (A). Subkriteria tersebut dikategorikan menjadi lima kelas vegetasi yaitu sangat buruk, buruk, sedang, baik, dan sangat baik, dan diklasifikasi untuk dapat diberikan rangking dan mendapatkan bobot pada setiap daerah aliran sungai. Rangking untuk subkriteria tutupan lahan dapat dilihat pada Tabel 2. Klasifikasi tutupan lahan dibuat dalam bentuk peta yang dapat dilihat pada Gambar 3 .

Tabel 2

Rangking dan bobot subkriteria

\begin{tabular}{llccc}
\hline Kriteria & \multicolumn{1}{c}{ Subkriteria } & Kelas & Rangking & Bobot \\
\hline \multirow{2}{*}{ TUTUPAN } & Hutan Mangrove Sekunder & Sangat Rendah & 1 & 0.022 \\
\cline { 2 - 5 } LAHAN & Hutan Lahan Kering Sekunder & Sangat Rendah & 1 & 0.022 \\
\hline & Hutan Lahan Kering Primer & Sangat Rendah & 1 & 0.022 \\
\hline & Perkebunan & Rendah & 2 & 0.044 \\
\hline & Belukar Rawa & Sedang & 3 & 0.067 \\
\hline Belukar & Sedang & 3 & 0.067 \\
\hline & Pertanian Lahan Kering & Tinggi & 4 & 0.089 \\
\hline Tanah Terbuka & Sangat Tinggi & 5 & 0.111 \\
\hline Tambak & Sangat Tinggi & 5 & 0.111 \\
\hline & Sawah & Sangat Tinggi & 5 & 0.111 \\
\hline Permukiman & Sangat Tinggi & 5 & 0.111 \\
\hline Bandara/Pelabuhan & Sangat Tinggi & 5 & 0.111 \\
\hline Badan Air & Sangat Tinggi & 5 & 0.111 \\
\hline
\end{tabular}

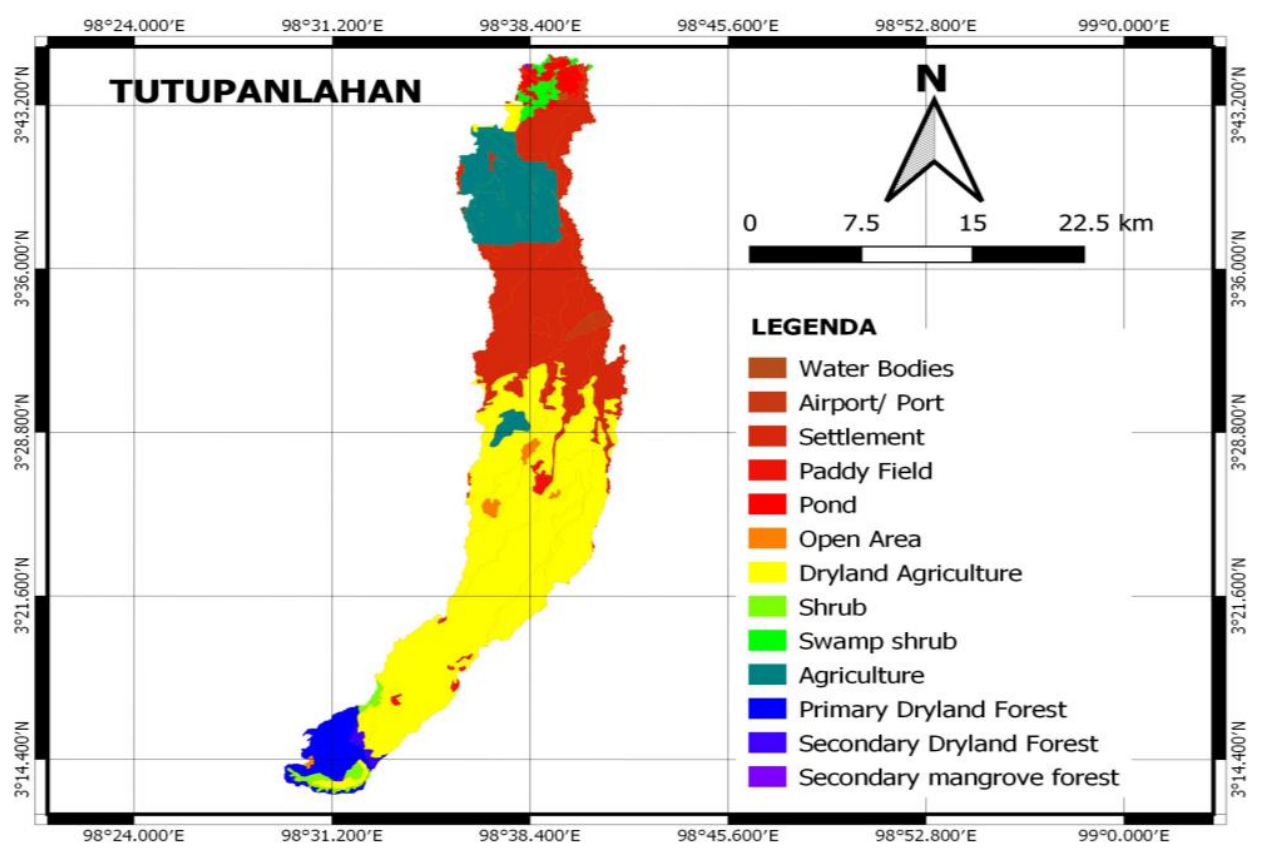

Gambar 3

Peta tutupan lahan 
Selanjutnya adalah kriteria tanah, kelas kriteria tanah adalah nilai erodibilitas tanah K. Erodibilitas tanah adalah kondisi mudah atau tidaknya tanah tersebut tererosi (Kurniawati, 2010; Asdak, 2004). Data erodibilitas pada wilayah studi berdasarkan hasil analisa Jenis (ordo) tanah. Pada daerah penelitian terdapat 2 golongan orde tanah yang dibagi menjadi 5 suborde dan 10 great group tanah. Klasifikasi dari erodibilitas tanah pada lokasi penelitian dan pemberian rangking untuk mendapatkan nilai bobot dapat dilihat pada Tabel 3, dan kelas tersebut dibuat dalam bentuk peta tematik menggunakan bantuan perangkat lunak QGIS dapat dilihat pada Gambar 4.

Tabel 3

Bobot subkriteria tanah

\begin{tabular}{lllcc}
\hline Kriteria & \multicolumn{1}{c}{ Subkriteria } & \multicolumn{1}{c}{ Kelas } & \multirow{2}{*}{ Rangking } & \multirow{2}{*}{ Bobot } \\
\hline Tanah & Erodibilitas (K): 0 - 0,05 & Sangat Rendah & 1 & 0.067 \\
\hline & Erodibilitas (K): $0,05-0,1$ & Rendah & 2 & 0.133 \\
\hline & Erodibilitas (K): 0,1 - 0,15 & Sedang & 3 & 0.200 \\
\hline Erodibilitas (K): 0,15-0,2 & Tinggi & 4 & 0.267 \\
\hline Erodibilitas (K): $>0,2$ & Sangat Tinggi & 5 & 0.333 \\
\hline
\end{tabular}

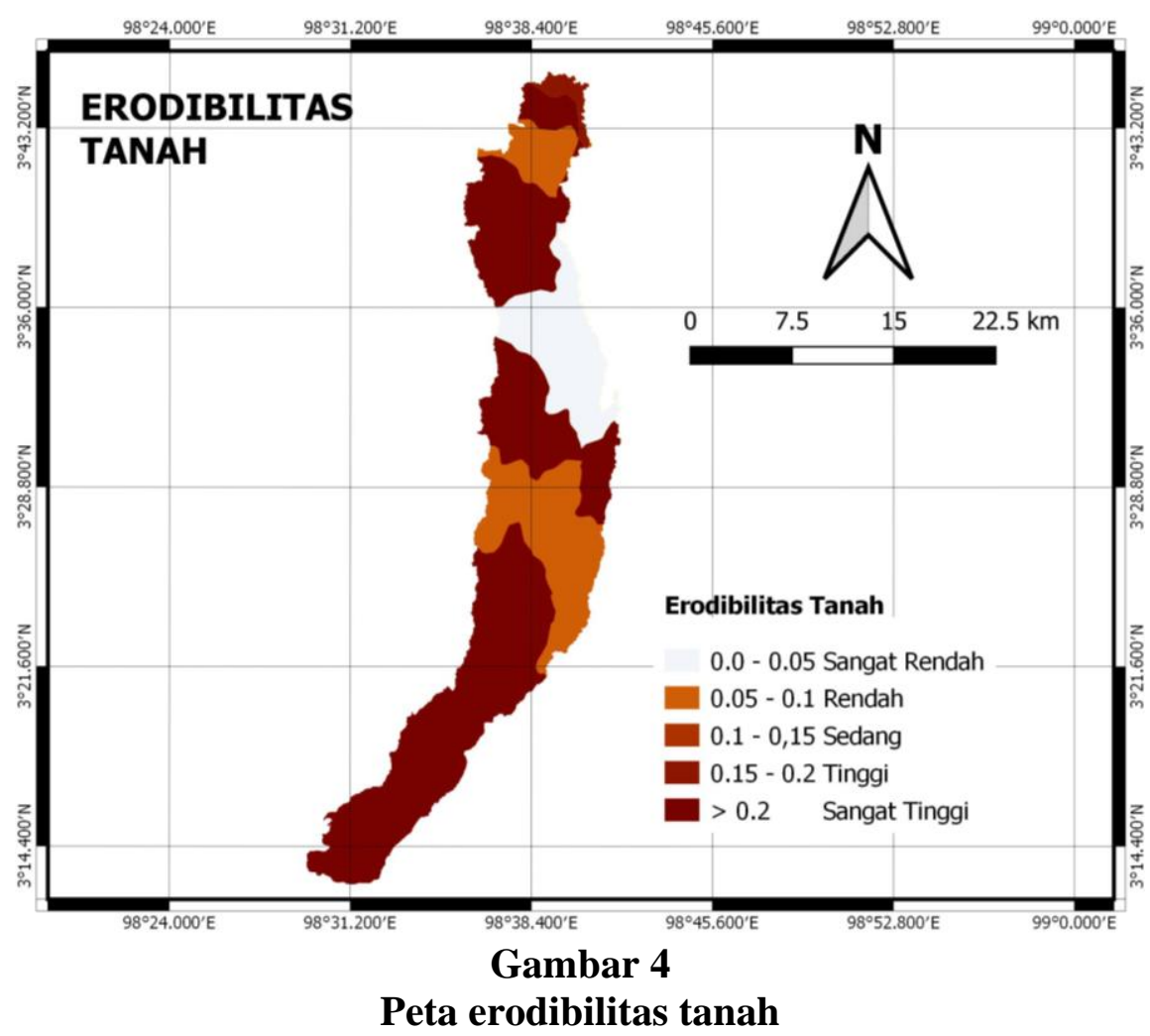

Subkriteria dari kemiringan lahan diklasifikasi menjadi lima kelas berdasarkan persentase kemiringan lahan pada daerah penelitian. Wilayah dengan kemiringan lahan yang tinggi diberikan rangking yang lebih besar. Rangking dan bobot 
kemiringan lahan dapat dilihat pada Tabel 4. Peta kemiringan lahan dibuat dengan perangkat lunak QGIS menggunakan data DEM NAS. Kemiringan lahan $0-8 \%$ diklasifikasi menjadi kelas sangat rendah, 8 -15\% kelas rendah, $15-25 \%$ kelas sedang, $25-45 \%$ kelas tinggi, $>45 \%$ kelas sangat tinggi. Peta kemiringan lahan tersebut juga dibuat dalam bentuk peta tematik yang dapat dilihat pada Gambar 5 .

Tabel 4

Bobot subkriteria kemiringan lahan

\begin{tabular}{cllcc}
\hline Kriteria & \multicolumn{1}{c}{ Subkriteria } & \multicolumn{1}{c}{ Kelas } & Rangking & Bobot \\
\hline Kemiringan lereng & $0-8 \%$ & Sangat Rendah & 1 & 0.067 \\
\hline & $8-15 \%$ & Rendah & 2 & 0.133 \\
\hline & $15-25 \%$ & Sedang & 3 & 0.200 \\
\hline $25-45 \%$ & Tinggi & 4 & 0.267 \\
\hline & $>45 \%$ & Sangat Tinggi & 5 & 0.333 \\
\hline
\end{tabular}

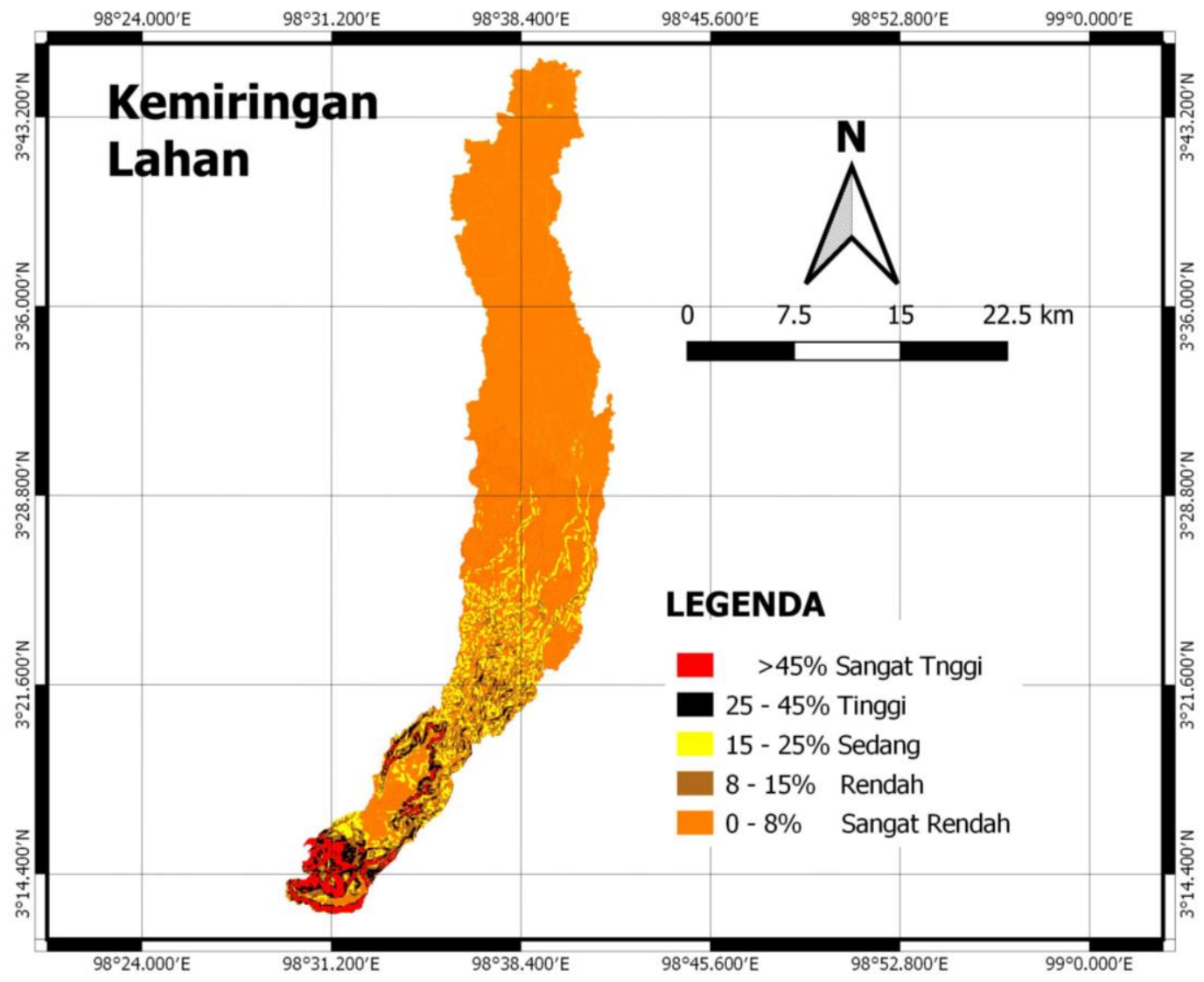

\section{Gambar 5}

Peta kemiringan lahan

Data curah hujan yang digunakan adalah curah hujan tahunan rata-rata dari tahun 2006-2015, data ini didapat dari dari Badan Meteorologi Klimatologi Geofisika (BMKG ) dalam bentuk peta tematik. Curah hujan diklasifikasi menjadi 3 
kelas yaitu curah hujan 500 - 1000 mm kelas rendah, curah hujan 1500 - 2500 kelas sedang, dan curah hujan K000 - 2500 kelas tinggi. klasifikasi tinggi juga diberikan bobot yang lebih tinggi berdasarkan pada pengaruh curah hujan terhadap potensi erosi. Klasifikasi subkriteria curah hujan dapat dilihat pada Tabel 5. Peta curah hujan dapat dilihat pada Gambar 6.

\section{Tabel 5}

Bobot subkriteria curah hujan

\begin{tabular}{cllcc}
\hline Kriteria & \multicolumn{1}{c}{ Subkriteria } & \multicolumn{1}{c}{ Kelas } & Rangking & \multirow{2}{*}{ Bobot } \\
\hline Curah Hujan & $500-1000 \mathrm{~mm}$ & Rendah & 2 & 0.222 \\
\hline & $1500-2000 \mathrm{~mm}$ & Sedang & 3 & 0.333 \\
\hline & $2000-2500 \mathrm{~mm}$ & Tinggi & 4 & 0.444 \\
\hline
\end{tabular}

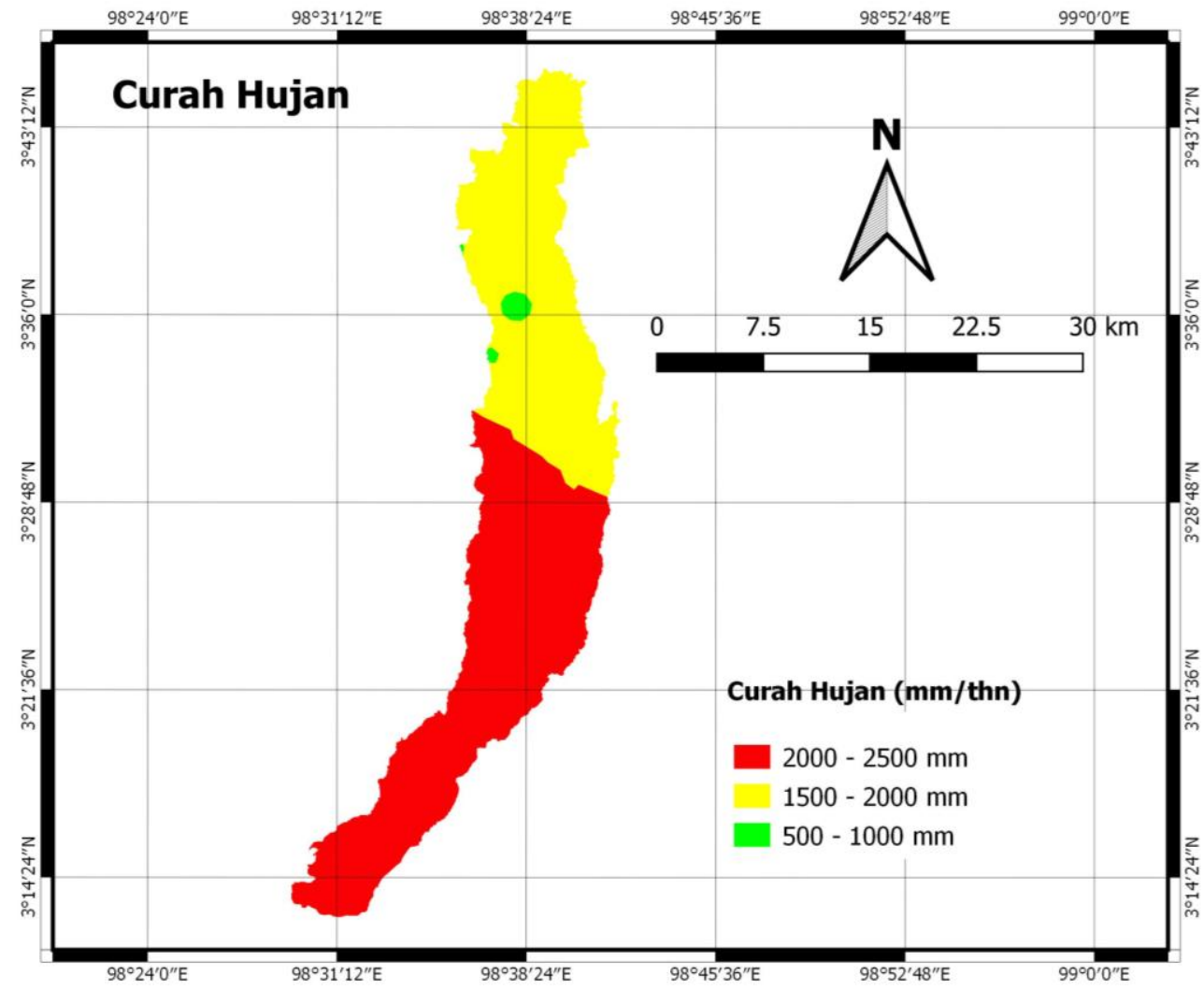

Gambar 6

Peta curah hujan

Kelas kriteria kerapatan sungai dapat dilihat pada Tabel 6. Nilai kerapatan sungai yang tinggi, potensi erosi semakin besar. Kerapatan sungai adalah perbandingan antara panjang sungai dengan luas daerah alirannya. Klasifikasi kerapatan sungai dapat dilihat dalam bentuk peta pada Gambar 7 . 
Tabel 6

Bobot subkriteria kerapatan sungai

\begin{tabular}{|c|c|c|c|c|}
\hline Kriteria & Subkriteria & Kelas & Rangking & Bobot \\
\hline \multirow[t]{5}{*}{$\begin{array}{l}\text { Kerapatan Sungai } \\
\left(\mathrm{km} / \mathrm{km}^{2}\right)\end{array}$} & $0-0,25$ & Sangat Rendah & 1 & 0.267 \\
\hline & $0,25-0,5$ & Rendah & 2 & 0.333 \\
\hline & $0,5-0,75$ & Sedang & 3 & 0.222 \\
\hline & $0,75-1$ & Tinggi & 4 & 0.333 \\
\hline & $>1$ & Sangat Tinggi & 5 & 0.444 \\
\hline
\end{tabular}

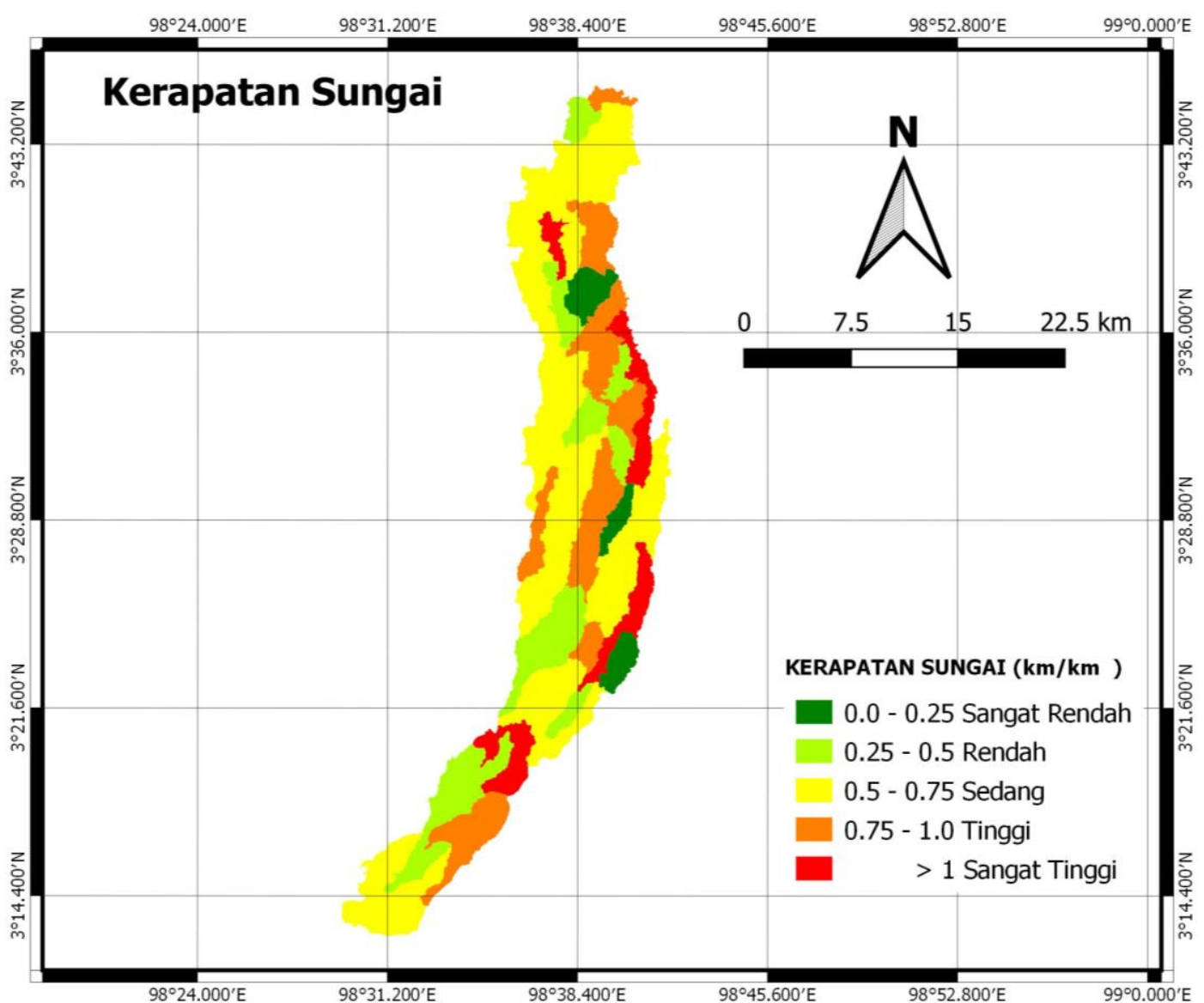

Gambar 7

Peta kerapatan sungai

\section{Prioritas Pengelolaan Mikro DAS}

Bobot kriteria utama dan bobot subkriteria dikalikan untuk mendapatkan nilai Prioritas pengelolaan mikro DAS. Urutan prioritas dilakukan dengan memberikan rangking pada setiap mikro DAS berdasarkan pada nilai indeks potensi erosi. Urutan nilai indeks potensi tersebut kemudian diklasifikasi menjadi 4 kelas prioritas yaitu rendah, sedang, tinggi, dan sangat tinggi. Klasifikasi empat kelas prioritas mikro DAS yaitu prioritas rendah dengan nilai indeks potensi erosi $(0,098-0,119)$, 
prioritas sedang $(0,119-0,144)$, prioritas tinggi $(0,144-0,169)$, dan prioritas sangat tinggi $(0,169-0,201)$. Klasifikasi prioritas tersebut dapat dilihat pada Tabel 7.

\section{Tabel 7}

Peta prioritas mikro DAS

\begin{tabular}{clccc}
\hline \multirow{2}{*}{ NO. } & \multirow{2}{*}{ Klasifikasi } & Jumlah mikro das & Luas (ha) & Persentase (\%) \\
\hline 1 & Rendah & 5 & 3,271 & 8 \\
\hline 2 & Sedang & 12 & 10,418 & 24 \\
\hline 3 & Tinggi & 27 & 23,370 & 54 \\
\hline 4 & Sangat Tinggi & 9 & 5,914 & 14 \\
\hline \multicolumn{2}{r}{ Total } & 53 & 42,973 & 100 \\
\hline
\end{tabular}

Setiap kelas prioritas diberi notasi warna sehingga dapat ditampilkan dalam bentuk peta tematik seperti pada Gambar 8. Kelas rendah diberi warna kuning, kelas sedang warna hijau, kelas tinggi warna jingga dan kelas sangat tinggi warna merah.

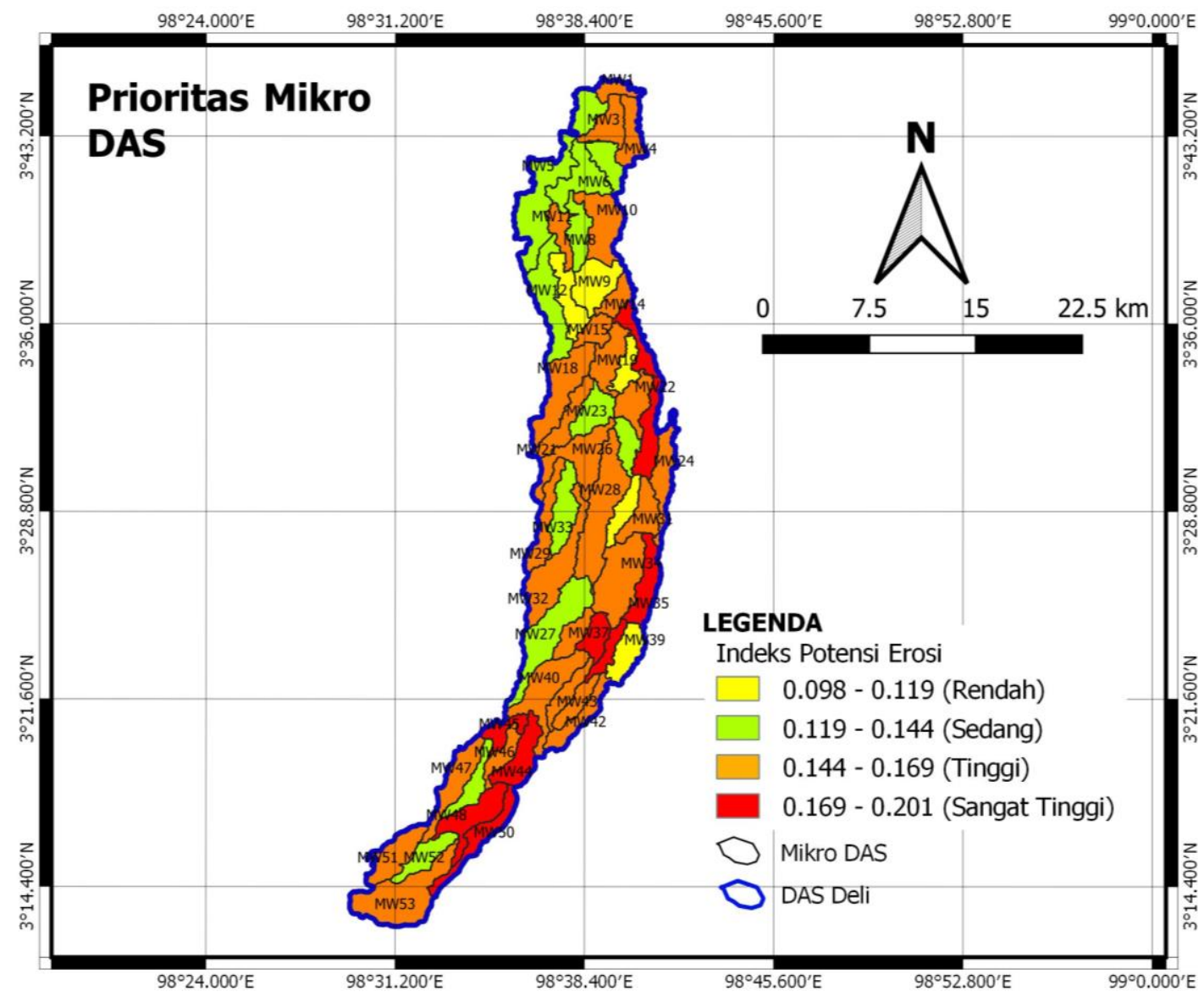

Gambar 8

Peta prioritas mikro DAS

Pada Gambar 8 menunjukkan mikro DAS yang membutuhkan penanganan pengelolaan dan konservasi DAS berdasarkan empat kelas prioritas. Terdapat 5 
Mikro DAS yang masuk dalam prioritas rendah dengan total luas 3.271 ha, prioritas sedang 12 mikro DAS dengan luas total 10.418 ha, prioritas tinggi 27 mikro DAS dengan luas total 23.370 ha, dan prioritas sangat tinggi 9 mikro DAS dengan luas total 5.914 ha. Pada Tabel 5. dapat dilihat persentase luas wilayah untuk klasifikasi prioritas rendah adalah 8 persen dari luas DAS Deli, kelas sedang 24 persen, kelas tinggi 54 persen, dan kelas sangat tinggi 14 persen.

\section{Kesimpulan}

Pada penelitian ini indeks potensi erosi digunakan untuk mendapatkan prioritas pengelolaan DAS Deli dalam ukuran mikro yang berada di kabupaten Deli Serdang, kabupaten Karo, dan kota Medan provinsi Sumatera Utara. Batas DAS dalam ukuran mikro yang dibuat dengan perangkat lunak QGIS menghasilkan 53 mikro DAS. Setiap mikro DAS dihitung nilai indeks potensi erosi untuk mendapatkan urutan prioritas pengelolaan dan konservasi. Indeks potensi erosi merupakan suatu nilai tanpa satuan yang membantu dalam pengindeksan zona potensi erosi pada daerah aliran sungai berdasarkan pada Geographical Information System (GIS) dan metode AHP. Indeks potensi erosi memiliki kelebihan karena menggunakan data yang mudah didapatkan dan proses perhitungan yang sederhana. Data yang digunakan adalah data yang berhubungan dengan daerah aliran sungai seperti tutupan lahan, tanah, kemiringan lahan, kerapatan sungai, dan curah hujan. Hasil perhitungan adalah 27 mikro DAS dari 53 mikro DAS masuk dalam kelas prioritas tinggi dengan luas 23.370 ha atau $54 \%$, dan prioritas sangat tinggi 9 mikro DAS dengan luas total 5.914 ha atau $14 \%$ dari luas DAS Deli secara keseluruhan. Data hasil perhitungan ini menunjukkan bahwa $68 \%$ dari total luas DAS Deli perlu segera dilakukan pengelolaan dan konservasi karena berada pada kategori prioritas tinggi dan sangat tinggi. 


\section{BIBLIOGRAFI}

Bali, Y. P., \& Karale, R. L. (1977). A sediment yield index as a criterion for choosing priority basins. IAHS-AISH Publication, 122, 180-188. Google Scholar

Chowdary, V. M., Chakraborthy, D., Jeyaram, A., Murthy, Y. V. N. Krishna, Sharma, J. R., \& Dadhwal, V. K. (2013). Multi-criteria decision making approach for watershed prioritization using analytic hierarchy process technique and GIS. Water Resources Management, 27(10), 3555-3571. Google Scholar

Ekadinata, Andree, Dewi, Sonya, Hadi, D., Nugroho, D., \& Johana, Feri. (2008). Sistem informasi geografis untuk pengelolaan bentang lahan berbasis sumber daya alam. Bogor, Yudhistira. Google Scholar

Fallah, Moghadaseh, Kavian, Ataollah, \& Omidvar, Ebrahim. (2016). Watershed prioritization in order to implement soil and water conservation practices. Environmental Earth Sciences, 75(18), 1-17. Google Scholar

Isma, Faiz, Irwansyah, Irwansyah, \& Neneng, Ipak. (2017). Analisa Potensi Erosi Pada Das Deli Sumatera Utara Menggunakan Sistem Informasi Geografis (SIG). JURUTERA-Jurnal Umum Teknik Terapan, 4(01), 25-36. Google Scholar

Nanda, A.M., Aadil, H.M., Zahoor, U.H., Pervez, A. dan Tasawoor, A. .. (2015). Watershed Prioritization Using Sediment Yield Index Model for Vishav Watershed of Jammu and Kashmir State (India). J. Himalayan Ecol. Sustian. Dev. Vol. 10.

Naqvi, Hasan Raja, Athick, A. S. Mohammed Abdul, Ganaie, Hilal Ahmad, \& Siddiqui, Masood Ahsan. (2015). Soil erosion planning using sediment yield index method in the Nun Nadi watershed, India. International Soil and Water Conservation Research, 3(2), 86-96. Google Scholar

Pandey, Ashish, Chowdary, V. M., \& Mal, B. C. (2007). Identification of critical erosion prone areas in the small agricultural watershed using USLE, GIS and remote sensing. Water Resources Management, 21(4), 729-746. Google Scholar

Purwanto, Beny, H., dan Agung, B. .. (2016). Belajar Dari Pengalaman Pengelolaan Daerah Aliran Sungai (Das) Mikro. Surakarta: UNS Press.

Saaty T L. (1980). The analytic hierarchy process. Mc Graw Hill, New York 237. Google Scholar

Siregar, P. Zandiba, Tarigan, A. Perwira Mulia, Irsan, Muhammad, \& Irwandi, Hendri. (2019). GIS-Based Flood Mitigation of Deli River. IOP Conference Series: Materials Science and Engineering, 505(1), 12125. IOP Publishing. Google Scholar

Tarigan, A. P. M., Surbakti, M. S., Sembiring, S. I. (2017). Studi penentuan prioritas peningkatan ruas jalan (studi kasus: ruas jalan Provinsi di Kabupaten Samosir). Jurnal Program Pasca Sarjana, Departemen Teknik Sipil, Universitas Sumatera Utara, Medan. 
Tarigan, A. P. M., Rahmad, D., Sembiring, R. A., \& Iskandar, R. (2018). An application of the AHP in water resources management: a case study on urban drainage rehabilitation in Medan City. IOP Conference Series: Materials Science and Engineering, 309(1), 12096. IOP Publishing. Google Scholar

Terranova, O., Antronico, L., Coscarelli, R., \& Iaquinta, P. (2009). Soil erosion risk scenarios in the Mediterranean environment using RUSLE and GIS: an application model for Calabria (southern Italy). Geomorphology, 112(3-4), 228-245. Google Scholar

Tetzlaff, Björn, \& Wendland, Frank. (2012). Modelling sediment input to surface waters for German states with MEPhos: methodology, sensitivity and uncertainty. Water Resources Management, 26(1), 165-184. Google Scholar

Vrieling, Anton. (2006). Satellite remote sensing for water erosion assessment: A review. Catena, 65(1), 2-18. Google Scholar

Welde, Kidane. (2016). Identification and prioritization of subwatersheds for land and water management in Tekeze dam watershed, Northern Ethiopia. International Soil and Water Conservation Research, 4(1), 30-38. Google Scholar

Wischmeier, Walter H., \& Smith, Dwight David. (1978). Predicting rainfall erosion losses: a guide to conservation planning. Department of Agriculture, Science and Education Administration. Google Scholar

\section{Copyright holder:}

Khairi Fadhlan, A Perwira Mulia Tarigan, dan Zaid Perdana Nasution (2021)

First publication right:

Journal Syntax Literate

This article is licensed under:

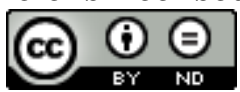

